\title{
Research on the cartoon culture and national image construction
}

\author{
LiuYuehua, LiuJin
}

\author{
Nanchang Institute of Science \& Technology, Nanchang 330108,China
}

\section{Key words: cartoon culture; national culture; image construction}

\begin{abstract}
With the economic globalization, the world is increasingly closely linked, Chinese animation culture has been the impact of foreign culture. This paper expounds the current situation of China's animation and animation culture, from the cultural influence on all aspects of our country to analyze the image of China's construction of the improvement effect that will be the cartoon culture and national image construction work closely together, greatly enhance our national culture influence, has important practical significance to further enhance China's influence in the international arena.
\end{abstract}

\section{Introduction}

Animation culture is a new culture which combines cartoon image with new media in the Internet era, it is a form of popular visual culture, including animation, comics, cartoon and animation image and related other consumer products etc.. Animation culture on the art of their own culture, but also a subtle influence on the national image, which is to expand the country's culture and external image is constantly playing a role. The animation of the exotic has occupied the Chinese film market, the Chinese with a strong impact of cartoon culture. Professor Guo Hong has suggested that if the monopoly of the Chinese market monopoly of foreign animation market in China, then it will not only bring significant losses to China's economy, more serious is that it will weaken our national spirit. We have to integrate Chinese culture into the animation, to enhance the quality of China's own animation, so that young people to absorb their traditional national culture, national self-confidence. Therefore, the development of animation on the national image and enhance the national culture has important practical significance

\section{The present situation and analysis of Chinese cartoon culture}

In the middle of 20th Century, our country has developed the animation culture, has produced many outstanding animation works. However, these glorious times have become history, since China experienced the "Cultural Revolution", China's animation and cultural progress has become slow. Although in recent years, the government intends to strengthen the construction of animation culture, and take some means to increase investment, but the status quo is still not optimistic, and lack of national culture can be displayed works. Compared with the developed countries, China's animation industry is still in a backward position, the lack of cultural powers due to the world's competitiveness. In recent decades, China's animation industry has been chasing the pace of the national market, although the number of original animation more and more, but it is really recognized by the audience is very rare. With the economic globalization, many foreign animation works into the domestic market. According to the survey, the most popular Japanese animation in the country, followed by Europe and the United States, not recognized domestic animation. There are two main reasons for this phenomenon, one reason is that the children born in twenty-first Century is mainly love animation, they live in is full of exotic culture era, which leads to children's 
habit of absorbing foreign culture. With Doraemon, soccer boy, tennis boy, Altman and other animation products caused by Japan and Europe and the United States cartoon characters to the children left a deep impression. On the other hand, it is difficult to attract the audience to meet the love, a lot of cartoon characters are imitation of foreign products for the lack of domestic animation with Chinese characteristics. In fact, culture is the foundation and guarantee of the animation industry, if the animation industry does not have its own cultural characteristics, then the animation industry is lost its direction. Tracing back to the history of the development of animation, the animation was also Chinese brilliant, in 1940s, Shanghai Wan brothers have made the first full-length animated film "Princess Iron Fan" according to the "journey to the west", issued to Southeast Asia and Japan, warmly welcomed by the people, for the Chinese International Animation make a good bedding. The animated film "Iron Fan Princess" is able to achieve great success, mainly because it shows the world a profound national culture and national spirit. Animation culture must be based on culture, cohesion of China's extensive and profound traditional culture and the unique thinking of the Chinese nation, in order to show the world the spirit of Chinese culture and cultural charm of animation works.

\section{Brief analysis of the impact of animation culture}

Animation culture affects our youth. Now, the child after the birth of the first general to see his mother, and then the toys, the next contact is the most animated. Therefore, animated cartoons accompany children throughout the child's stage, this is a great impact on children life, values and world views. At the same time, it plays a subtle role in children's social cognitive ability. All in all, the animation culture is a double-edged sword, which plays a positive and negative influence in the process of children's growth. The positive effect is: with the implementation of family planning in China, most families have only one child, they grew up in the absence of small partners, they like to close themselves up. By watching cartoons, children can think of the protagonist of the anime as a character of their own. Children can feel the virtual world from the anime created in individuality, their own unique personality and consciousness can be cultivated, in their spiritual home belong to children, which will bring some effect on their psychological barrier. The negative effect is that, with the emergence of animation, some children are addicted to watching animation, affecting the healthy development of their physical and mental health, so that they have a sense of inferiority, paranoia, anxiety.

The influence of cartoon culture on national image. National image refers to other countries' overall evaluation and feeling of the country, and cultural communication is one of the important means to shape the image of a country. In the cultural exchange process, animation culture has become the main carrier of national cultural diplomacy, through the show to other countries contains national characteristics of the animation products, we can show the broad and profound national culture to other countries, the construction of China's big country image.

The influence of cartoon culture on national culture. The development of animation should be based on the animation culture as the main starting point, only to promote the animation culture in advance, the animation industry will have a broader space. Each country according to its traditional culture to create animation works, the animation industry is the country's mark, for example, the Disney film, it can become a symbol of American culture, because of the animation works can always give people show the humanistic characteristics and behavior logic. If a country's animation and cultural fields are ruled by other countries, then the country's national culture in the future may also be affected by other countries.

The influence of cartoon culture on national economy. With the continuous progress and 
development of animation industry, it is popular among young people, and has gradually become the world economic growth, economic development has become an important field of the United States, Japan and South Korea, the animation powerhouse, with the development of the more important for the economic development of these countries. In addition, the animation culture can create a good atmosphere for the consumption of animation products, prompting people to actively participate in animation activities, and promote their consumption development. Since 21th Century, as the three pillar industries of Japan's economy, the annual income of hundreds of billions of yen. Enough to see how important the animation culture to promote national economic development.

\section{The significance of cartoon culture to the construction of national image}

Create a sense of identity in animation products. Chinese animation and the national image to build together, first of all should be in the animation products to create a sense of identity, which requires people to make efforts in two areas, the first is to vigorously develop the cultural perspective and modern consciousness, and actively explore and evaluate the traditional culture of the Chinese nation. Animation combines the spirit of humanity, ideology and industrial level of art form, it has been loved by people, because it can show people the national image, values and institutional culture. Chinese animation to expand its influence on the world, it is necessary to broaden the cultural perspective of history, focus on human consciousness and modern spirit. On the other hand, if you want to create the impression of the animation, it is necessary to strengthen the national culture reflected in the animation works, at the same time, it is necessary to strengthen the use of Chinese in the role of animation, language can show the spirit of a nation, values, aesthetic taste, cultural quality, etc., based on the language of the carrier, it can be carried by the cultural values of its extension to the place where the spread of Chinese language is the world to spread Chinese culture, so that the world to understand China's an important way.

Expand the spread of ways to play multiple effects. With the continuous development and progress of information technology, the way of information transmission is increasing, which makes the communication channels of animation become diversified. People can make use of newspapers, television, network, computer to show people animation works, but also to create an evaluation system for people to evaluate the animation work. This animation creators can find their own works and the lack of change, then bring better animation works for people. Good animation works can also be transformed into comics or games, people love the animation changed by a game, spread in the masses, can let more see this work, and the cultural connotation can be realized, which is advantageous in the construction of national image play multiple effect.

Strengthen exchanges and cooperation with the international community. In terms of international cooperation, 2006 Jilin College of The Arts animation school ready to cooperate with Japan animation development center primary school hall, funds provided by the Chinese side, the Japanese in technology shares in the form of technology, the main creative staff of Jilin animation base for technical training, and is responsible for the design of the two party together to create " The marquis guan yu" this cartoon. In strengthening the international animation and cultural exchanges, a good way is to hold the International Animation Festival, which attracts the world's participation, to strengthen exchanges between countries effectively, show China's cultural soft power to his country.

\section{Conclusion}

Overall, exploration of "national image" in China, whether in theory or in the arts are in a initial 
stage, and the construction of "national image" is constantly moving up in the future development process. In the field of Chinese animation, "national image" construction should make sense of identity, broaden the channels of communication and strengthen the international cooperation. At the same time, more attention should be paid to the spirit and cultural character of the Chinese nation. This mission requires a more comprehensive understanding of the culture, and the cultural tradition and the characteristics of the national spirit also need to be further studied.

\section{Acknowledgement}

The work was supported by the art planning project in Jiangxi with the project number YG2015088 and the project name Research on Cartoon Culture and the Construction of National Image.

\section{Reference}

[1] Tao Yilin. Study on the artistic characteristics of Chinese school animation film music [D]. Hangzhou Normal University, (2015)

[2] Xu Kebin. Identity and construction of domestic animation culture in the context of globalization [D]. Southwestern University, (2015)

[3] Xu Jiankang, Deng Jinxian. Analysis of the influence of Chinese traditional culture on animation design [J]. Movie Review, Vol.12, (2014), p.80-81.

[4] Li Wenjia. The inheritance and development of Chinese traditional costumes of women in the cartoon image [D]. Shaanxi Normal University, (2013)

[5] Zheng Xiufen. On the win win strategy in the combination of animation industry and traditional culture [J]. Movie Literature, No.01, (2013) , p.59-60.

[6] Liu Zhiming. The research on the image building and development of. [D]. Guangdong University of Technology, (2012)

[7] Ji Xiao. Research on the performance of cartoon image based on brand building [D]. Henan University, (2012)

[8] Liao Lingyan. A comparative study of the brothers and the animation works of [D]., Zhejiang Sci-Tech University,, (2011)

[9] Zhou Chen. The evolution of cultural ecology and the development of Chinese animated films [D]. Soochow University, (2011)

[10] Xiao Xin. Animation culture and its influence [J]. Movie Literature, No. 02, (2011) , p.55-56.

[11] Cui Meiyan. Study on the national image in media communication [D]. Heilongjiang University, (2010)

[12] Zheng Xi. The study of Chinese animation creation in the era of visual culture [D]. Jiangnan University, (2009)

[13] Yang Yang. On the traditional culture expression and development of Chinese animation [D]. Shandong University, (2009)

[14] Wang Luan. In the cultural globalization China animation research [D]. Heilongjiang University, (2008) 
[15] Dong Qingling. On the construction of national image under the background of globalization [D]. Shandong Normal University, (2006)

[16] Xiao Lu. The traditional aesthetic style and cultural origin of domestic animated films [D]. East China Normal University, (2006)

[17] Jin Tianyi. China Tianyi animation school began forming and mature [J]. Film Art, No.01, (2004), p.57-60. 